\title{
QUANTITATIVE VARIATION IN THE TROPICAL MAIZE POPULATION, ESALQ-PB1
}

\author{
João Antonio da Costa Andrade ${ }^{1 *}$; José Branco de Miranda Filho² \\ ${ }^{1}$ UNESP/FE - Depto. de Biologia e Zootecnia, C.P. 31 - 15385-000 - Ilha Solteira, SP - Brasil. \\ ${ }^{2}$ USP/ESALQ - Depto. de Genética, C.P. 83 - 13418-900 - Piracicaba, SP - Brasil. \\ *Corresponding author <jandrade@bio.feis.unesp.br>
}

\begin{abstract}
Good yield and intermediate plant height, ear height, and tassel size characterize the maize population ESALQ-PB1 as an outstanding breeding population. Estimates of genetic parameters are reported for 13 traits: plant height $(\mathrm{PH})$, ear height $(\mathrm{EH})$, ear placement (EP), tassel length (TL), tassel weight (TW), tassel branch number (TB), ear weight (EW), total grain weight (GW), ear length (EL), ear diameter (ED), kernel row number (RN), kernel number per row (KR) and prolificacy (PR). Results refer to one location and one year. Genetic variation was detected for all traits, and the estimates of the additive genetic variance are presented. The coefficients of heritability (individual basis) varied from 0.14 to 0.72 and were considered high for PH, EH and TB; intermediate for EP, TL, TW, EL, EP, ED and RN, and low for EW, GW, KR and PR. The coefficient of heritability (progeny mean basis) showed approximately the same trend and varied from 0.40 to 0.75 . The highest expected gain from selection was for TB $(27 \%$ per cycle) under mass selection and for TW (16.4\%) under progeny selection; the lowest expected gain was for ED either for mass selection $(1.9 \%)$ or progeny selection $(2.9 \%)$. Additive correlation coefficients $\left(\mathrm{r}_{\mathrm{A}}\right)$ of $0.5<\mathrm{r}_{\mathrm{A}}<0.6$ were found for $\mathrm{PH}$ or $\mathrm{EH}$ and yield traits (EW and $\mathrm{GW}$ ) and its components EL and $\mathrm{KR}$, and $0.10<r_{A}<0.44$ for $\mathrm{PH}$ or $\mathrm{EH}$ and tassel traits. For the tassel traits the highest correlation was $\mathrm{r}_{\mathrm{A}}=0.63$ (TB.TW). EP was positively correlated with TB, TW, PH, EH and PR; and negatively correlated with ED and RN. The expected correlated responses in several traits after selection for GW, EH and TB are given. Key words: genetic parameters, genetic variability, heritability, recurrent selection
\end{abstract}

\section{VARIAÇÃOQUANTITATIVANA POPULAÇÃO TROPICAL DE MILHO, ESALQ-PB1}

\begin{abstract}
RESUMO: A boa produtividade e os valores intermediários para altura da planta e altura da espiga caracterizam a população de milho ESALQ-PB1 como agronomicamente promissora. São relatadas estimativas de parâmetros para 13 caracteres: altura da planta $(\mathrm{PH})$, altura da espiga (EH), posição relativa da espiga (EP), comprimento do pendão (TL), peso do pendão (TW), número de ramificações do pendão (TB), peso de espigas (EW), peso de grãos (GW), comprimento da espiga (EL), diâmetro da espiga (ED), número de fileiras de grãos $(\mathrm{RN})$, número de grãos por fileira $(\mathrm{KR})$ e prolificidade $(\mathrm{PR})$. Os resultados se referem a um único ambiente (um local e um ano). Foi detectada variação genética para todos os caracteres, e são apresentadas estimativas da variância genética aditiva. Os coeficientes de herdabilidade (indivíduos) variaram de 0,14 a 0,72 e foram considerados altos para PH, EH e TB; intermediários para EP, TL, TW, EL e ED, e baixos para EW, GW, KR e PR. O coeficiente de herdabilidade para médias de progênies mostrou aproximadamente a mesma tendência, variando de 0,40 a 0,75 . $\mathrm{O}$ maior ganho esperado por seleção foi para TB (27\% por ciclo) sob seleção massal e para TW (16,4\%) por seleção entre progênies; o menor ganho esperado foi para ED, tanto por seleção massal $(1,9 \%)$ como por seleção entre progênies $(2,9 \%)$. Coeficientes de correlação aditiva $\left(r_{A}\right) 0.5<r_{A}<0.6$ foram observados para PH ou EH e para os caracteres de produção (EW e GW) e seus componentes EL e KR, e $0,10<r_{A}<0,44$ para $\mathrm{PH}$ ou EH e caracteres do pendão. Para os caracteres do pendão a maior correlação foi $\mathrm{r}_{\mathrm{A}}=0,63$ (TB.TW). EP foi correlacionada positivamente com TB, TW, PH, EH e PR; e negativamente correlacionada com ED e RN. As respostas correlacionadas esperadas em diversos caracteres após seleção para GW, EH e TB são apresentadas.

Palavras-chave: parâmetros genéticos, variabilidade genética, herdabilidade, seleção recorrente
\end{abstract}

\section{INTRODUCTION}

Maize is a typically allogamous species with prevalence of cross pollination. The amount of self- fertilization in an ordinary field of maize is negligible (Kiesselbach, 1922). Therefore, a maize population is seen as a group of individuals that cross randomly among themselves in a panmitic way so that male and 
female gametes unite at random. The probability of an individual in the next generation be homozygous by descent is $1 / 2 \mathrm{~N}$ ( $\mathrm{N}$ is the population size) and a population sufficiently large can be maintained in equilibrium if no other forces (mutation, gamete migration, selection, random drift) lead to departure from its basic structure.

The genetic structure of a maize population under panmixy is very complex (Shull, 1908). For quantitative traits that are polygenically inherited the complexity arises from the great number of genotypes within a population and from allelic, non-allelic and genotype by environment interactions. For breeding purposes, the genetic structure of maize populations for quantitative traits has been studied on the basis of statistical parameters (e.g., mean, variance, correlation coefficient, and others). The basic concepts and statistical methods for estimation of genetic parameters are given by Cockerham (1963), Hallauer \& Miranda Filho (1995), Falconer \& Mackay (1996), Lynch \& Walsh (1997) and Cruz \& Carneiro (2003).

Parameter estimates refer to a particular population of genotypes (reference population) for a defined population of environmental effects (Cockerham, 1963); the estimates can, however, be compared among populations for their relative magnitudes and be used as a guide for effective handling in breeding programs. Parameter estimates for some important traits in maize populations were summarized in several opportunities (Miranda Filho, 1985; Vencovsky et al., 1987; Hallauer \& Miranda Filho, 1995). More recently, genetic parameters also estimate for others specific populations by Paterniani et al. (2004), Carvalho et al. (2005), Yazdi-Samadi et al. (2004), El-Bagoury et al. (2005), Zivanovic et al. (2005) and Salami et al. (2007).

The purpose of this study was to report about parameter estimates of 13 quantitative traits in the maize population ESALQ-PB1 and its potential for breeding. Particular attention was given to tassel branch number and ear height because ESALQ-PB1 was used as a base population for divergent selection of these traits.

\section{MATERIAL AND METHODS}

The reference population, ESALQ-PB1, is a composite formed from crosses among seven short plant varieties (Miranda Filho, 1974). After three generations of recombination and homogenization, it has undergone one cycle of stratified mass selection and one cycle of half-sib family selection. One thousand half-sib families were evaluated in the last cycle and high selection intensity (2\%) was used. After recombination of the selected 20 half-sib families, 147 open- pollinated ears (half-sibs) were used to represent the base population of this study.

The 147 half-sib families were evaluated in three $7 \times 7$ lattice experiments with four replications, at Piracicaba-Brazil $\left(22^{\circ} 39^{\prime} \mathrm{S}\right.$ and $47^{\circ} 35^{\prime} \mathrm{W}$, and 597 $\mathrm{m}$ of altitude), in 1978/79. Plots were $5 \mathrm{~m}$ long, spaced $1 \mathrm{~m}$ apart, with 25 plants after thinning. The following traits were taken for analysis: $\mathrm{PH}$ - plant height (m); EH - ear height (m); EP - ear placement; TL - tassel length $(\mathrm{cm})$; TW - tassel weight $(\mathrm{g})$; TB - tassel branch number; EW - ear weight (g); GW - grain weight $(\mathrm{g})$; EL - ear length $(\mathrm{cm})$; ED - ear diameter $(\mathrm{cm}) ; \mathrm{RN}$ - kernel row number; KN - kernel number per row; and PR - prolificacy. The traits EL, ED, RN, $\mathrm{KN}$ and PR were taken in only two experiments (98 families). Actually, this is a selection project and the experimental layout was designed according to this purpose. The quantitative traits analyzed herein took only part of the experiments, so that a sample of size five was taken within plots to measure plant, tassel or ear characteristics.

Because the low efficiency of the lattice design in relation to the randomized complete block design, all the analyses of variance and covariance were performed as complete block design with plot means and the variation within plots was included. The basic model is:

$\mathrm{Y}_{\mathrm{ijk}}=\mathrm{m}+\mathrm{p}_{\mathrm{i}}+\mathrm{b}_{\mathrm{j}}+\mathrm{e}_{\mathrm{ij}}+\mathrm{s}_{\mathrm{ijk}}$,

where $Y_{i j k}$ is the observation of the $k^{\text {th }}$ plant of the $i^{\text {th }^{h}}$ progeny in the $j^{\text {th }}$ replication; $m$ the overall mean; $p_{i}$ the random progeny effect (mean: 0 ; variance: $\sigma_{\mathrm{p}}^{2}$ ); $b_{j}$ the random block effect; $e_{i j}$ the experimental error (mean: 0; variance: $\sigma_{e}^{2}$ ), and $\mathrm{s}_{\mathrm{ijk}}$ the effect of the $\mathrm{k}^{\text {th }}$ plant (mean: 0 ; variance $\sigma^{2}{ }_{\mathrm{w}}$ ) in the $\mathrm{ij}{ }^{\text {th }}$ plot. The analyses of variance and covariance are shown in Table 1 with the mean squares $\left(\mathrm{M}_{1}\right.$ and $\left.\mathrm{M}_{2}\right)$, mean products $\left(\mathrm{P}_{1}\right.$ and $\left.\mathrm{P}_{2}\right)$ and their respective expectations in terms of variance and covariance components. The following estimates were obtained of the individual analyses grouping:

- Genetic variance among progenies.. $\hat{\sigma}_{\mathrm{p}}^{2}=\left(\mathrm{M}_{1}-\mathrm{M}_{2}\right) / \mathrm{r}$

- Plot-to-plot environmental variance.. $\hat{\sigma}_{\mathrm{e}}^{2}=\mathrm{M}_{2}-\mathrm{M}_{3} / \mathrm{k}$

- Phenotypic variance within progenies.......... $\hat{\sigma}_{\mathrm{w}}^{2}=\mathrm{M}_{3}$

- Additive genetic variance............. $\hat{\sigma}_{\mathrm{A}}^{2}=4\left(\mathrm{M}_{1}-\mathrm{M}_{2}\right) / \mathrm{r}$

- Additive genetic covariance (traits $\mathrm{x}$ and $\mathrm{y}$ ) $\operatorname{Cov}_{\mathrm{A}}=4\left(\mathrm{P}_{1}-\mathrm{P}_{2}\right) / \mathrm{r}$

- Coefficient of heritability (individual)

$$
. . h^{2}=\sigma_{\mathrm{A}}^{2} /\left(\sigma_{\mathrm{p}}^{2}+\sigma_{\mathrm{e}}^{2}+\sigma_{\mathrm{w}}^{2}\right)=\sigma_{\mathrm{A}}^{2} / \sigma_{\mathrm{F}}^{2}
$$


- Coefficient of heritability (progeny mean)

$$
\mathrm{h}_{\mathrm{p}}^{2}=\left(\mathrm{M}_{1}-\mathrm{M}_{2}\right) / \mathrm{M}_{1}
$$

- Additive correlation coefficient..... $\mathrm{r}_{\mathrm{A}}=\operatorname{Cov}_{\mathrm{Ax} . \mathrm{y}} / \sigma_{\mathrm{Ax}} \cdot \sigma_{\mathrm{Ay}}$

- Phenotypic (means) correlation coefficient

$$
. . r_{m}=P_{1 x y} /\left(M_{1 x} \cdot M_{1 y}\right)^{1 / 2}
$$

- Expected genetic gain: HS selection

$$
\mathrm{G}_{\mathrm{HS}}=\mathrm{i} \mathrm{h}_{\mathrm{p}}^{2}\left(\mathrm{M}_{1} / \mathrm{r}\right)^{1 / 2}
$$

- Expected genetic gain: Mass selection

$$
. . \mathrm{G}_{\mathrm{M}}=\mathrm{i} \mathrm{h}^{2} \sigma_{\mathrm{F}}
$$

- Expected correlated response: HS selection

$$
\mathrm{R}_{\mathrm{HS}}=\mathrm{i} \frac{1}{4} \operatorname{Cov}_{\mathrm{Ax} . \mathrm{y}} /\left(\mathrm{M}_{1} / \mathrm{r}\right)^{1 / 2}
$$

- Expected correlated response: Mass selection

$$
. . \mathrm{R}_{\mathrm{M}}=\mathrm{i} \operatorname{Cov}_{\mathrm{Ax} . \mathrm{y}} / \sigma_{\mathrm{Fx}}
$$

- Experimental coefficient of variation

$$
\text { ..CVe }(\%)=100\left[\mathrm{M}_{2}\right]^{1 / 2} / \mathrm{m}
$$

- Genetic coefficient of variation

$$
\operatorname{CVg}(\%)=100 \quad \hat{\sigma}_{\mathrm{p}} / \mathrm{m}
$$

- Index of variation.

$$
\mathrm{IV}=\mathrm{CVg} / \mathrm{CVe}
$$

The estimates involving PH, EH, EP, TL, TW, TB, EW and GW, were calculated on basis in 147 families (three experiments). For EL, ED, RN, KN and PR such as its correlations with PH, EH, EP, TL, TW, TB, EW and GW, were considered only 98 families (two experiments).

\section{RESULTS AND DISCUSSION}

Means of half-sib families and their respective ranges for 13 traits in the maize population ESALQ$\mathrm{PB} 1$ are shown in Table 2. For plant height $(\mathrm{PH})$ and ear height $(\mathrm{EH})$ the population should be classified as intermediate, as compared to other brazilian populations. Ear placement (EP) indicates that on the average the ear is located in the upper half of the stalk, but the range of variation ( 0.475 to 0.535$)$ indicates that EP can be reduced through selection. The tassel characteristics did not differ greatly from other populations (Geraldi et al., 1985; Souza Jr. et al., 1985). Tassels had an average length (TL) of $40.9 \mathrm{~cm}$ and the average weight (TW) was $5.9 \mathrm{~g}$. The tassel branch number (TB) deserves special attention because it is the primary trait used in the selection for tassel size

Table 1 - Analysis of variance and covariance for individual experiments.

\begin{tabular}{lccccc}
\hline Source & d.f. & MS & E(MS) & MP & E(MP) \\
\hline Replications & $\mathrm{r}-1$ & --- & --- & --- & -- \\
Progenies & $\mathrm{n}-1$ & $\mathrm{M}_{1}$ & $\sigma_{\mathrm{w}}^{2} / \mathrm{k}+\sigma_{\mathrm{e}}^{2}+\mathrm{r}_{\mathrm{p}}^{2}$ & $\mathrm{P}_{1}$ & $\operatorname{Cov}_{\mathrm{w}} / \mathrm{k}+\operatorname{Cov}_{\mathrm{e}}+\mathrm{rCov}_{\mathrm{p}}$ \\
Error & $(\mathrm{n}-1)(\mathrm{r}-1)$ & $\mathrm{M}_{2}$ & $\sigma_{\mathrm{w}}^{2} / \mathrm{k}+\sigma_{\mathrm{e}}^{2}$ & $\mathrm{P}_{2}$ & $\operatorname{Cov}_{\mathrm{w}} / \mathrm{k}+\operatorname{Cov}_{\mathrm{e}}$ \\
Within & $\mathrm{nr}(\mathrm{k}-1)$ & $\mathrm{M}_{3}$ & $\sigma_{\mathrm{w}}^{2}$ & $\mathrm{P}_{3}$ & $\operatorname{Cov}_{\mathrm{w}}$ \\
\hline
\end{tabular}

MS and MP: mean squares and mean products; $n, r$, $k$ : number of progenies, replications and plants per plot, respectively; $\mathrm{k}$ was not constant for all traits

Table 2 - Mean, range (minimum and maximum), coefficients of variation $\left(\mathrm{CV}_{\mathrm{e}}\right.$ : experimental; $\mathrm{CV}_{\mathrm{g}}$ : genetic) and index of variation (Iv) for 13 traits of the maize population ESALQ-PB1.

\begin{tabular}{lcccccc}
\hline Traits & mean & min. & max. & $\mathrm{CV}_{\mathrm{e}}(\%)$ & $\mathrm{CV}_{\mathrm{g}}(\%)$ & $\mathrm{Iv}$ \\
\hline Plant height $(\mathrm{cm})$ & 231.3 & 194.5 & 257.7 & 4.38 & 3.80 & 0.869 \\
Ear height $(\mathrm{cm})$ & 124.0 & 100.8 & 146.0 & 7.21 & 5.33 & 0.740 \\
Ear placement & 0.535 & 0.475 & 0.593 & 5.29 & 3.02 & 0.570 \\
Tassel length $(\mathrm{cm})$ & 40.90 & 36.09 & 45.99 & 5.02 & 4.10 & 0.815 \\
Tassel weight $(\mathrm{g})$ & 5.87 & 3.92 & 7.98 & 13.2 & 10.9 & 0.827 \\
Tassel branch number & 18.4 & 12.6 & 23.8 & 11.4 & 9.99 & 0.873 \\
Ear weight $(\mathrm{g})$ & 185.5 & 142.6 & 234.7 & 14.6 & 5.92 & 0.406 \\
Grain weight $(\mathrm{g})$ & 150.8 & 110.1 & 192.6 & 15.7 & 6.34 & 0.403 \\
Ear length $(\mathrm{cm})$ & 17.54 & 13.88 & 19.77 & 6.71 & 4.63 & 0.690 \\
Ear diameter $(\mathrm{cm})$ & 4.81 & 4.47 & 5.13 & 3.89 & 2.18 & 0.560 \\
Kernel row number & 14.11 & 12.59 & 16.79 & 5.67 & 4.76 & 0.840 \\
Kernels per row & 35.3 & 26.4 & 41.4 & 9.17 & 4.67 & 0.509 \\
Prolificacy & 1.12 & 1.00 & 1.40 & 14.2 & 5.93 & 0.416 \\
\hline
\end{tabular}


(Mock \& Pearce, 1975). Tassel branch number averaged 18.4 branches per tassel, varying from 12.6 to 23.8, which would be considered as intermediate values as compared to other populations. Average of 26.5 branches per tassel was reported for 338 samples representing races of maize from several countries, varying from 17.7 (Bolivian races) to 42 (Colombian races) (Paterniani, 1981). Averages of 18.1, 22.4 and 18.7 branches/tassel in three broad-base populations (Centralmex, Flint Composite and Dent Composite, respectively) also were reported (Geraldi et al., 1985). Variation from 17.5 to 33.2 for TB are found in the maize population SUWAN (Souza Jr. et al., 1985). Average of 15.8 branches/tassel, varying from 6.9 to 22.5 , were found among 15 exotic populations (Miranda Filho, 1992), while the mean for the population ESALQ-PB1 was 20.4.

The means for EW (185.5 g) and GW (150.8 g) per plant were greater than the average of 107 mean estimates of Brazilian populations (Miranda Filho, 1985) and the population RPM (Resistant to Phaeosphaeria maydis) and RET (Resistant to Exserohilum turcicum) (Miranda Filho \& Gorgulho, 2003) and Composite I-Mo (Paterniani et al., 2004). The greater range of variation (Table 2) for these traits is an expression of their high genetic variability, however other populations of broad genetic basis present larger estimates (Cárdenas, 2005; El-Bagoury et al., 2005). The EL varied from 13.9 to $19.8 \mathrm{~cm}$, averag- ing $17.5 \mathrm{~cm}$. For ED a small variation $(4.5$ to $5.1 \mathrm{~cm})$ was observed, while the RN and KR showed a wide variability, ranging from 12.6 to 16.8 and 26.4 to 41.4 , respectively. Prolificacy, as measured by the average number of ears per plant under a population density of 50,000 plants ha ${ }^{-1}$, varied from 1.0 to 1.4 among half sib families.

The experimental coefficient of variation $(\mathrm{CVe})$ varied from $3.9 \%$ to $15.7 \%$ among traits and the genetic coefficient of variation $(\mathrm{CVg})$ ranged from $2.2 \%$ to $10.0 \%$ (Table 2). The ratio $\mathrm{Iv}=\mathrm{CVg} / \mathrm{CVe}$ (Vencovsky, 1987; Vencovsky \& Barriga, 1992) designated as index of variation (Valois, 1982) showed higher estimates (0.7 to 0.9) for PH, EH, TL, TW, TB, EL and RN, while smaller estimates (0.4 to 0.6) were found for EP, EW, GW, ED, KR and PR. Estimates of Iv for EW (0.7 and 0.5), PH (0.4 and 0.7) and EH (0.5 and 0.7) in two population (Miranda Filho \& Gorgulho, 2003), were similar those showed in this study and also the estimates for a dwarf population in reduced spacing (Candido, 2005). However, estimates greater than one for this traits in dwarf population evaluated in density of 80,000 plants/ha were obtained for Garcia (2005). Higher Iv estimates indicate greater opportunities for selection, and Iv $>1$ would indicate a favorable condition for selection purposes (Vencovsky, 1987).

In the analysis of variance (Table 3 ) significant variation was detected for all traits, thus allow-

Table 3 - Analysis of variance (mean squares and degrees of freedom between parenthesis) for traits plant height (PH), ear height (EH), ear placement (EP), tassel length (TL), Prolificacy (PR), tassel weight (TW), tassel branch number (TB), ear weight (EW), grain weight (GW), ear length (EL), ear diameter (ED), kernel row number (RN) and kernels per row (KR), of the maize population ESALQ-PB1.

\begin{tabular}{|c|c|c|c|c|c|c|}
\hline Traits & \multicolumn{2}{|c|}{ Progenies } & \multicolumn{2}{|c|}{ Error } & \multicolumn{2}{|c|}{ Within } \\
\hline \multicolumn{7}{|c|}{ Plant and tassel traits } \\
\hline $\mathrm{PH}$ & 411.8 & (144) & 102.4 & $(432)$ & 311.2 & $(2349)$ \\
\hline EH & 254.9 & (144) & 79.96 & $(432)$ & 232.0 & $(2349)$ \\
\hline $\mathrm{EP}^{4}$ & 18.41 & (144) & 8.00 & $(432)$ & 27.19 & $(2349)$ \\
\hline $\mathrm{PR}^{4}$ & 433.1 & $(96)$ & 256.0 & $(288)$ & 986.1 & $(1510)$ \\
\hline $\mathrm{TL}$ & 15.44 & (144) & 4.222 & $(432)$ & 23.93 & $(2342)$ \\
\hline TW & 2.253 & (144) & 0.603 & $(432)$ & 3.491 & $(2342)$ \\
\hline TB & 18.02 & (144) & 4.449 & $(432)$ & 17.99 & $(2342)$ \\
\hline \multicolumn{7}{|c|}{ Ear traits } \\
\hline EW & 1211.8 & (144) & 729.6 & $(432)$ & 3202.7 & (2290) \\
\hline GW & 928.2 & (144) & 563.0 & $(432)$ & 2431.0 & $(2290)$ \\
\hline EL & 4.025 & $(96)$ & 1.385 & (288) & 6.088 & (1510) \\
\hline $\mathrm{ED}^{3}$ & 79.05 & (96) & 35.08 & (288) & 158.2 & (1510) \\
\hline $\mathrm{RN}$ & 2.445 & (96) & 0.639 & (288) & 3.281 & (1510) \\
\hline KR & 21.35 & (96) & 10.48 & (288) & 49.78 & $(1510)$ \\
\hline
\end{tabular}

3,4- Mean squares multiplied by $10^{3}$ and $10^{4}$, respectively. 
ing estimates of variance components and other parameters (Table 4). The estimates of the additive genetic variance for PH $\left(309.3 \mathrm{~cm}^{2}\right)$ and $\mathrm{EH}\left(175.0 \mathrm{~cm}^{2}\right)$ did not differ greatly from the average (321.0 and $218.0 \mathrm{~cm}^{2}$, respectively) of 16 estimates summarized by Miranda Filho (1985) in brazilian populations, but smaller than seven populations $\left(972.4 \mathrm{~cm}^{2}\right.$ and 749.2 $\mathrm{cm}^{2}$ ), evaluated by Cárdenas (2005). The estimates were, however, greater for $\mathrm{PH}$ and about the same for EH in relation to 45 estimates summarized by Hallauer \& Miranda Filho (1995). The additive variance for GW also was greater (365.2 $\mathrm{g}^{2}$ ) as compared to the average $\left(306.0 \mathrm{~g}^{2}\right)$ of 36 populations reported by Miranda Filho (1985), for CMS population (Carvalho et al., 2002) and CPATC-3 population (Carvalho et al., 2003). Estimates of $854.0 \mathrm{~g}^{2}$ and $865.0 \mathrm{~g}^{2}$, same after five and six selection cycles in BR5011 population, were obtained by Carvalho et al. (2000). The same level of variability was also observed for EW that was smaller than obtained by Miranda Filho \& Gorgulho (2003), Paterniani et al. (2004) and Cárdenas (2005). The additive variance for EL $\left(2.64 \mathrm{~cm}^{2}\right)$ and for ED $(0.044$ $\mathrm{cm}^{2}$ ) were greater and similar as compared to the average $\left(1.52 \mathrm{~cm}^{2}, 0.046 \mathrm{~cm}^{2}\right.$, respectively) of $36 \mathrm{popu}-$ lations (Hallauer \& Miranda Filho, 1995). The estimate for PR (0.018), however was lower than the average (0.046) reported by Hallauer \& Miranda Filho (1995). The estimates of the additive genetic variance for the tassel traits were $11.2 \mathrm{~cm}^{2}, 1.65 \mathrm{~g}^{2}$ and 13.6 for TL, TW, and TB, respectively. The estimate for TB (13.6) was smaller than that reported (18.9) by Kassouf \& Miranda Filho (1986) for ESALQ-PB1, but was greater than estimates for three different broad base populations reported by Geraldi et al. (1985). Additive variance estimates for TB varied from 4.0 to 53.1 in 40 estimates summarized by Araújo (1992), who found an estimate of 15.4 for ESALQ-PB1. For RN and KR the estimated additive variance were 0.018 and 10.9 , respectively.

The estimates of the coefficients of heritability on an individual plant basis (Table 4) varied from 0.141 to 0.721 and were higher for $\mathrm{PH}, \mathrm{EH}$, and TB, intermediate for EP, TL, TW, EL, ED, and RN, and low for EW, GW, KR, and PR. The heritability estimates on progeny mean basis followed approximately the same trend and varied from 0.394 to 0.753 , showing that some traits such GW and the yield components KR and PR can be more effectively selected on the basis of progeny means, while others exhibiting high individual heritability can be effectively selected on the basis of phenotypic expression. In general, the heritability estimates did not differ from estimates summarized by Geraldi et al. (1985), Miranda Filho (1985), Souza Jr. et al. (1985), Hallauer \& Miranda Filho (1995) and Miranda Filho \& Gorgulho (2003). For PH, EH, PR, EW and GW, estimates consistently

Table 4 - Estimates of the additive genetic variance $\left(\sigma_{\mathrm{A}}^{2}\right)$, coefficients of heritability ( $\mathrm{h}^{2}$ to individual and $\mathrm{h}_{\mathrm{m}}^{2}$ to progeny mean basis) and expected gain from selection $\left(\mathrm{G}_{\mathrm{H}}\right.$ to half-sib family selection and $\mathrm{G}_{\mathrm{M}}$ to mass selection) for the traits plant height (PH), ear height (EH), ear placement (EP), tassel length (TL), Prolificacy (PR), tassel weight (TW), tassel branch number (TB), ear weight (EW), grain weight (GW), ear length (EL), ear diameter (ED), kernel row number (RN) and kernels per row (KR), of the maize population ESALQ-PB1.

\begin{tabular}{|c|c|c|c|c|c|c|c|}
\hline \multirow[b]{2}{*}{ Traits } & \multirow[b]{2}{*}{$\sigma_{\mathrm{A}}^{2}$} & \multirow[b]{2}{*}{$\mathrm{h}^{2}$} & \multirow[b]{2}{*}{$\mathrm{h}_{\mathrm{m}}^{2}$} & \multicolumn{4}{|c|}{ Expected gain } \\
\hline & & & & $\mathrm{G}_{\mathrm{H}}$ & $\%$ & $\mathrm{G}_{\mathrm{M}}$ & $\%$ \\
\hline $\mathrm{PH}$ & 309.3 & 0.721 & 0.751 & 13.4 & 5.78 & 26.2 & 11.3 \\
\hline $\mathrm{EH}$ & 175.0 & 0.566 & 0.686 & 9.62 & 7.76 & 17.4 & 14.1 \\
\hline $\mathrm{EP}^{5}$ & 104.1 & 0.322 & 0.565 & 0.02 & 3.98 & 0.03 & 6.00 \\
\hline $\mathrm{TL}$ & 11.22 & 0.429 & 0.727 & 2.51 & 6.13 & 1.92 & 4.71 \\
\hline TW & 1.65 & 0.433 & 0.732 & 0.96 & 16.4 & 0.74 & 12.6 \\
\hline TB & 13.57 & 0.610 & 0.753 & 2.81 & 15.2 & 5.05 & 27.4 \\
\hline EW & 482.1 & 0.141 & 0.398 & 12.1 & 6.55 & 7.24 & 3.90 \\
\hline GW & 365.2 & 0.141 & 0.394 & 10.5 & 6.98 & 6.29 & 4.17 \\
\hline EL & 2.640 & 0.382 & 0.656 & 1.15 & 6.58 & 0.88 & 5.02 \\
\hline $\mathrm{ED}^{4}$ & 439.7 & 0.255 & 0.556 & 0.14 & 2.85 & 0.09 & 1.93 \\
\hline $\mathrm{RN}$ & 1.805 & 0.486 & 0.738 & 1.01 & 7.18 & 0.82 & 5.83 \\
\hline KR & 10.86 & 0.205 & 0.509 & 2.06 & 5.84 & 1.31 & 3.71 \\
\hline $\mathrm{PR}^{4}$ & 177.1 & 0.163 & 0.409 & 0.07 & 6.64 & 0.09 & 8.41 \\
\hline
\end{tabular}

4,5 - Estimates of $\sigma_{A}^{2}$ multiplied by $10^{4}$ and $10^{5}$, respectively. $\mathrm{G}_{\mathrm{H}}-10 \%$ : both sexes; $\mathrm{G}_{\mathrm{M}}-10 \%$ for both sexes for PH, EH, TB and PR and for female sex for other traits. 
greater were obtained by Candido (2005), Cárdenas (2005) and Garcia (2005). For GW, similar estimates were obtained in the BR 5011, CMS 35 and CPATC-3 brazilian populations (Carvalho et al., 2000, 2002 and 2003). All the estimates presented herein refer to only one environment (one location and one year) so that they may be overestimated by an amount proportional to the genotype by environment interaction when considering a sample of environments represented by several locations and/or years.

The expected gains from selection (Table 4) reflect, in most of the traits, their estimates of heritability; i.e., traits that exhibited higher heritability showed higher predicted gains for both mass selection and progeny selection. The greatest predicted gain from mass selection was for TB (27\% per cycle) and from progeny selection was for TW (16.4\% per cycle). The lowest expected gain was for ED from either mass selection $(1.9 \%)$ or progeny selection $(2.8 \%)$. When comparing mass selection with progeny selection on a per cycle basis, the mass selection was expected to be more effective for PH (11.3 vs. 5.8\%), EH (14.1 vs. 7.8\%) and TB (27.4 vs. $15.2 \%)$. PH, EH, and TB had the highest estimates for heritability coefficient and index of variation. The same comparison indicated progeny selection as more effective for TW (12.6 vs. 16.4\%), EW (4.0 vs. $6.5 \%)$ and GW (4.2 vs. $7.0 \%)$. TW, GW, and EW had lower heritability estimates and are selected after flowering; i.e., for the female sex only. For the other traits, the expected gains showed smaller differences between selection schemes.

The efficiency of mass selection for increasing $\mathrm{GW}$, as based on expected gains, is relatively lower as compared to those reported by Ayala Osuna (1977), Rissi (1980) and Bianco (1984) for other populations. Progeny selection, however, was more effective as reported by Souza Jr. (1983), Bianco (1984), Santos \& Naspolini Filho (1986), Candido (2005), Garcia (2005) and Carvalho et al. (2005). The realized gains tend to be lower than the expected ones, as indicated by the results summarized by Hallauer \& Miranda Filho (1995), which varied from 1.1 to $3.4 \%$ per cycle for mass selection and from $1.8 \%$ to $13.6 \%$ per cycle for progeny selection. In progeny selection scheme, the expected gain for $\mathrm{PH}$ and $\mathrm{EH}$ (5.8 and 7.8\%) were smaller than other populations: 7.9 and $12.3 \%$ (Candido, 2005); 12.2 and $19.1 \%$ (Garcia, 2005); 10.3 and 15.5\% (Cárdenas, 2005). For GW and PR the estimates of Candido (2005) (16.9 and 11.1\%) and Garcia (2005) (23.7 and 12.4\%) also were consistently greater than in the ESALQ-PB1 population (7.0 and 6.6\%).

The expected gain for $\mathrm{PH}$ and $\mathrm{EH}$ in the base population ESALQ-PB1 indicated mass selection as more effective than selection among half-sib progenies.
The same trends were not observed by other authors when considering selection within progenies in the recombination block (Ayala Osuna, 1977; Lordelo, 1982; Souza Jr., 1983; Soares Filho, 1987). For TB the efficiency of mass selection (27\% per cycle) is comparable to that expected for the variety Centralmex (23.2\% per cycle) and higher than that expected for Dent Composite (10.9\%) and Flint Composite (13.4\%) in which, however, a lower selection pressure $(20 \%)$ was considered (Geraldi et al., 1985). Among the tassel traits, TB is indicated when selecting for tassel size due to its high heritability, and because it is easily evaluated in the field and highly correlated to TW (Geraldi et al., 1985).

The additive genetic correlation $\left(\mathrm{r}_{\mathrm{A}}\right)$ and phenotypic correlation $\left(r_{p}\right)$ on progeny mean basis (Table 5) were positive for most pairs of traits. $\mathrm{PH}$ and $\mathrm{EH}$ had $\mathrm{r}_{\mathrm{A}}$ between 0.48 and 0.60 with yield traits (EW and $\mathrm{GW}$ ) and its components (EL and KR), which are in a higher level in relation to reports summarized by Hallauer \& Miranda Filho (1995) as well as in relation to some Brazilian populations (Lima, 1977; Lima \& Paterniani, 1977; Crisóstomo, 1978; Sampaio, 1986; Soares Filho, 1987). Positive correlations, however, do not preclude selection for pairs of traits in opposite direction to be effective. $\mathrm{PH}$ and $\mathrm{EH}$ were positively correlated to tassel traits with $\mathrm{r}_{\mathrm{A}}$ varying from 0.10 (EH.TL) to 0.44 (EH.TB). Also are reported positive genetic and phenotypic correlations between $\mathrm{PH}$ and EH with tassel traits (TB and TL) in the range of 0.135 to 0.438 (Farias Neto \& Miranda Filho, 2001). For the tassel traits (Table 5) the highest correlation was for TB.TW $\left(r_{A}=0.63\right)$. Correlation of TB and TW were positive and low $\left(r_{A}\right.$ between 0.02 and 0.22$)$ with the yield traits and higher $\left(\mathrm{r}_{\mathrm{A}}\right.$ between 0.19 and 0.40$)$ with EL. Both additive and phenotypic correlation between TW and TL was around 0.22 , which are very close to the genetic correlation $(0.232)$ reported by Farias Neto \& Miranda Filho (2001).

The correlations indicate a low indirect effect on yield when selecting for tassel size. Although TB and TW are negatively correlated to $\mathrm{PR}\left(\mathrm{r}_{\mathrm{A}}=-0.41\right.$ and $r_{A}=-0.48$, respectively), PR showed no correlation $\left(r_{A}\right.$ $=0.09)$ to the yield traits. High negative correlation between TB and PR in the maize population SUWAN and a high correlation $\left(r_{A}=0.94\right)$ between $G W$ and PR also were reported by Souza Jr. et al. (1985). Also estimated the expected correlated response $\left(\mathrm{R}_{\mathrm{s}}\right)$ on yield as 11.9 and $16.6 \%$ when selecting (20\% selection intensity) for decreasing TB and increasing PR, respectively. Our results indicated $\mathrm{R}_{\mathrm{s}}$ on yield of $-2 \%$ (Table $6)$ when selecting (10\% selection intensity) for decreasing $\mathrm{TB}$, as a consequence of the low correlation between TB and GW in spite of the higher heritability for TB (Falconer \& Mackay, 1996). 
Table 5 - Correlation coefficients (additive genetic above diagonal and phenotypic between means below diagonal) in combinations of traits plant height (PH), ear height (EH), ear placement (EP), tassel length (TL), prolificacy (PR), tassel weight (TW), tassel branch number (TB), ear weight (EW), grain weight (GW), ear length (EL), ear diameter (ED), kernel row number (RN) and kernels per row (KR), of the maize population ESALQ-PB1.

\begin{tabular}{lrrrrrrrrrrrrr}
\hline & PH & EH & EP & TL & TW & TB & EW & GW & EL & ED & RN & KR & PR \\
\hline PH & --- & $\mathbf{0 . 8 4 2}$ & $\mathbf{0 . 2 0 2}$ & $\mathbf{0 . 2 7 3}$ & $\mathbf{0 . 2 4 6}$ & $\mathbf{0 . 3 7 9}$ & $\mathbf{0 . 5 9 4}$ & $\mathbf{0 . 5 9 8}$ & 0.541 & -0.267 & -0.207 & 0.575 & 0.179 \\
EH & $\mathbf{0 . 8 0 3}$ & --- & $\mathbf{0 . 6 9 8}$ & $\mathbf{0 . 1 0 1}$ & $\mathbf{0 . 3 8 6}$ & $\mathbf{0 . 4 3 6}$ & $\mathbf{0 . 5 0 6}$ & $\mathbf{0 . 4 9 7}$ & 0.513 & -0.471 & -0.338 & 0.480 & 0.318 \\
EP & $\mathbf{0 . 1 8 4}$ & $\mathbf{0 . 7 3 0}$ & --- & $\mathbf{- 0 . 1 6 6}$ & $\mathbf{0 . 3 9 8}$ & $\mathbf{0 . 2 7 2}$ & $\mathbf{0 . 1 3 8}$ & $\mathbf{0 . 1 1 7}$ & 0.180 & -0.528 & -0.379 & 0.074 & 0.471 \\
TL & $\mathbf{0 . 2 3 5}$ & $\mathbf{0 . 0 9 4}$ & $\mathbf{- 0 . 1 0 6}$ & --- & $\mathbf{0 . 4 2 7}$ & $\mathbf{0 . 2 1 7}$ & $\mathbf{0 . 2 0 7}$ & $\mathbf{0 . 1 3 9}$ & 0.313 & -0.128 & 0.006 & 0.023 & -0.186 \\
TW & $\mathbf{0 . 2 3 3}$ & $\mathbf{0 . 3 4 7}$ & $\mathbf{0 . 3 1 7}$ & $\mathbf{0 . 4 1 1}$ & --- & $\mathbf{0 . 6 2 6}$ & $\mathbf{0 . 0 8 4}$ & $\mathbf{0 . 0 2 3}$ & 0.188 & 0.012 & 0.015 & 0.009 & -0.483 \\
TB & $\mathbf{0 . 3 3 9}$ & $\mathbf{0 . 3 8 2}$ & $\mathbf{0 . 2 2 6}$ & $\mathbf{0 . 2 2 4}$ & $\mathbf{0 . 6 0 3}$ & --- & $\mathbf{0 . 2 1 6}$ & $\mathbf{0 . 2 0 7}$ & 0.398 & -0.022 & 0.084 & 0.340 & -0.406 \\
EW & $\mathbf{0 . 4 1 7}$ & $\mathbf{0 . 3 7 8}$ & $\mathbf{0 . 1 4 9}$ & $\mathbf{0 . 1 6 5}$ & $\mathbf{0 . 2 2 3}$ & $\mathbf{0 . 1 7 8}$ & --- & $\mathbf{0 . 9 7 7}$ & 0.581 & -0.038 & -0.009 & 0.479 & 0.090 \\
GW & $\mathbf{0 . 4 1 5}$ & $\mathbf{0 . 3 6 3}$ & $\mathbf{0 . 1 2 7}$ & $\mathbf{0 . 1 2 6}$ & $\mathbf{0 . 1 8 4}$ & $\mathbf{0 . 1 7 4}$ & $\mathbf{0 . 9 8 3}$ & --- & 0.556 & -0.039 & -0.034 & 0.518 & 0.086 \\
EL & 0.437 & 0.394 & 0.108 & 0.298 & 0.258 & 0.318 & 0.591 & 0.569 & --- & -0.547 & -0.227 & 0.648 & -0.015 \\
ED & -0.112 & -0.233 & -0.260 & -0.047 & 0.116 & 0.023 & 0.254 & 0.257 & -0.197 & --- & 0.407 & 0.266 & -0.646 \\
RN & -0.131 & -0.219 & -0.229 & 0.048 & 0.071 & 0.107 & 0.060 & 0.045 & -0.138 & 0.415 & --- & 0.024 & -0.210 \\
KR & 0.435 & 0.355 & 0.056 & 0.062 & 0.133 & 0.235 & 0.563 & 0.575 & 0.664 & 0.020 & 0.022 & --- & -0.216 \\
PR & 0.104 & 0.237 & 0.325 & -0.081 & -0.245 & -0.225 & 0.245 & 0.222 & -0.023 & -0.369 & -0.124 & 0.052 & --- \\
\hline
\end{tabular}

\# Numbers in black: estimated with 147 progenies (three experiments); otherwise: estimated with 98 progenies (two experiments).

Table 6 - Expected correlated response on other traits after mass selection $(\mathbf{M})$ and half-sib family selection $(\mathbf{H})$ for grain yield $\left(\mathrm{R}_{\mathrm{G}}\right)$, ear height $\left(\mathrm{R}_{\mathrm{E}}\right)$, and tassel branch number $\left(\mathrm{R}_{\mathrm{T}}\right)$ of the maize population ESALQ-PB1.

\begin{tabular}{lccccccc}
\hline Traits & Selection schemes & $\mathrm{R}_{\mathrm{G}}$ & $\%$ & $\mathrm{R}_{\mathrm{E}}$ & $\%$ & $\mathrm{R}_{\mathrm{T}}$ & $\%$ \\
\hline Plant height (cm) & $\mathbf{H}$ & 5.78 & 2.50 & 10.8 & 4.65 & 5.07 & 2.19 \\
\hline Ear height (cm) & $\mathbf{M}$ & 1.97 & 0.85 & 11.1 & 4.81 & 5.21 & 2.25 \\
& $\mathbf{H}$ & 3.62 & 2.92 & --- & --- & 4.39 & 3.54 \\
\hline Ear placement & $\mathbf{M}$ & 1.23 & 0.99 & --- & --- & 4.51 & 3.64 \\
\hline Tassel length (cm) & $\mathbf{H}$ & $2 \times 10^{-3}$ & 0.39 & 0.02 & 3.06 & 0.07 & 1.25 \\
& $\mathbf{M}$ & $1 \times 10^{-3}$ & 0.13 & 0.01 & 1.22 & 0.01 & 1.28 \\
\hline Tassel weight (g) & $\mathbf{H}$ & 0.26 & 0.63 & 0.25 & 0.60 & 0.55 & 1.35 \\
& $\mathbf{M}$ & 0.09 & 0.21 & 0.25 & 0.62 & 0.57 & 1.39 \\
\hline Tassel branch number & $\mathbf{H}$ & 0.02 & 0.27 & 0.36 & 6.14 & 0.61 & 10.4 \\
& $\mathbf{M}$ & 0.01 & 0.09 & 0.37 & 6.35 & 0.63 & 10.7 \\
\hline Ear weight (g) & $\mathbf{H}$ & 0.35 & 1.92 & 4.02 & 5.56 & --- & --- \\
& $\mathbf{M}$ & 0.14 & 0.78 & 1.21 & 6.56 & --- & --- \\
\hline Grain weight (g) & $\mathbf{H}$ & 11.8 & 6.37 & 8.08 & 4.36 & 3.61 & 1.95 \\
& $\mathbf{M}$ & 4.02 & 2.17 & 8.36 & 4.51 & 3.71 & 2.00 \\
\hline Ear length (cm) & $\mathbf{H}$ & --- & --- & 6.91 & 4.58 & 3.01 & 2.00 \\
& $\mathbf{M}$ & --- & --- & 7.15 & 4.74 & 3.09 & 2.05 \\
\hline Ear diameter (cm) & $\mathbf{H}$ & 0.54 & 3.09 & 0.60 & 3.41 & 0.50 & 2.87 \\
& $\mathbf{M}$ & 0.19 & 1.10 & 0.62 & 3.53 & 0.55 & 3.12 \\
\hline Kernel row number & $\mathbf{H}$ & -0.01 & -0.10 & -0.07 & -1.47 & $-0.00^{+}$ & 0.08 \\
& $\mathbf{M}$ & $0.00^{+}$ & -0.04 & -0.07 & -1.52 & $-0.00^{+}$ & 0.08 \\
\hline Kernels per row & $\mathbf{H}$ & -0.03 & -0.19 & -0.32 & -2.31 & 0.09 & 0.62 \\
& $\mathbf{M}$ & -0.01 & -0.07 & -0.34 & -2.39 & 0.10 & 0.68 \\
\hline Prolificacy & $\mathbf{H}$ & 1.02 & 2.90 & 1.14 & 3.21 & 0.87 & 2.47 \\
& $\mathbf{M}$ & 0.36 & 1.03 & 1.17 & 3.32 & 0.95 & 2.68 \\
\hline
\end{tabular}

${ }^{+}$approximated values; $H$ - $10 \%$ both sexes; $\mathrm{M}$ - $10 \%$ female sex in $\mathrm{R}_{\mathrm{G}}$ and for both sexes in $\mathrm{R}_{\mathrm{E}}$ and $\mathrm{R}_{\mathrm{T}}$. 
Another important trait for the characterization of a better plant architecture in maize is EP, which was additively correlated with TB (0.27), TW (0.40), PH (0.20), EH (0.70), ED (-0.53), RN (-0.38), and PR (0.47). Although the correlation of EP with TB is not high (0.27), direct selection for decreasing TB will affect EP in the same direction; in the same way, selection for EH will affect both TB and EP.

The expected correlated responses in several traits through direct selection for $\mathrm{GW}, \mathrm{EH}$, and $\mathrm{TB}$ are shown in Table 6 for mass selection and progeny selection. If negative selection is practiced for TB or EH for better plant architecture, negative changes are expected in GW (2.0\% and $4.7 \%$ respectively); however, the changes in GW can be minimized by using no truncated selection to avoid undesirable genotypes for yield.

A combined selection, including TB as selection criterion for three populations, based on the negative correlation between GW and TB to increase the gain in GW were suggested by Geraldi et al. (1985). The low correlation between GW and TB observed in ESALQ-PB1 makes the selection for TB to be feasible without great changes in the mean yield. In a progeny selection program, selection in ESALQ-PB1 should be performed among progeny means for yield and within progenies for $\mathrm{EH}$ and $\mathrm{TB}$. In other populations and environments the expected correlated responses may be different as related by Garcia (2005) for dwarf maize in density of 80,000 plants/ha and reduced spacing. The expected correlated responses to family selection in GW was $8.8 \%, 15.1 \%$ and $9.5 \%$, respectively for $\mathrm{PH}, \mathrm{EH}$ and PR. With selection in $\mathrm{EH}$, the expected correlated responses was $10.9 \%, 18.0 \%$ and $7.1 \%$, for $\mathrm{PH}, \mathrm{GW}$ and PR, respectively. The same tendency of larger correlated responses so that obtained in ESALQPB1, also was observed by Candido (2005).

The estimates of parameters related to genetic variability in the maize population ESALQ-PB1, shown in this study, refer to only one environment (one location and one year), so that a random model for environment cannot be considered and the genotype ' environment interactions are not taken into account.

\section{REFERENCES}

ARAÚJO, P.M. Variabilidade genética em subpopulações de milho (Zea mays L.) obtidas por seleção divergente. Piracicaba: USP/ ESALQ, 1992. 153p. Dissertação (Mestrado).

AYALA OSUNA, J. Avaliação da seleção massal estratificada combinada com despendoamento de plantas inferiores em duas populações de Zea mays L. (milho) e da heterose dos seus cruzamentos. Jaboticabal: UNESP/FCAV, 1977. 138p. Tese (Livre-Docência).

BIANCO, S. Avaliação do potencial genético de populações de milho (Zea mays L.) braquítico para o teor de óleo na semente. Piracicaba: USP/ESALQ, 1984. 98p. Dissertação (Mestrado).
CANDIDO, L.S. Potencial do Composto Flintisa Anão de milho para melhoramento em condições de espaçamento reduzido e na safrinha. Ilha Solteira: UNESP/FE, 2005. 93p. Dissertação (Mestrado).

CÁRDENAS, F.E.N. Valor genético de populações de milho adaptadas para a região sudoeste de Goiás. Piracicaba: USP/ ESALQ, 2005. 169p. Tese (Doutorado).

CARVALHO, H.W.L.; LEAL, M.L.S.; SANTOS, M.X. Estimativas de parâmetros genéticos na população de milho CMS 35 no Estado de Sergipe. Pesquisa Agropecuária Brasileira, v.37, p.1399-1405, 2002.

CARVALHO, H.W.L.; LEAL, M.L.S.; SANTOS, M.X.; PACHECO, C.A.P. Potencial genético da cultivar de milho BR 5011: sertanejo nos tabuleiros costeiros do nordeste brasileiro. Pesquisa Agropecuária Brasileira, v.35, p.1169-1176, 2000.

CARVALHO, H.W.L.; LEAL, M.L.S.; SANTOS, M.X.; SOUZA, E.M. Estimativas de parâmetros genéticos na população de milho CPATC-3 em dois locais de Sergipe. Pesquisa Agropecuária Brasileira, v.38, p.73-78, 2003.

CARVALHO, H.W.L.; LEAL, M.L.S.; SANTOS, M.X.; SOUZA, E.M. Genetic parameters estimates in the maize variety BR 5033-Asa Branca in the State of Sergipe. Revista Científica Rural, v.10, p.95-101, 2005.

COCKERHAM, C.C. Estimation of genetic variances. In: HANSON, W.D.; ROBINSON, H.F. (Ed.) Statistical genetics and plant breeding. Washington: National Academy of Science, 1963. p.53-94. (NAS-NRC Publication, 982).

CRISÓSTOMO, J.R. Estimação de parâmetros genéticos visando seleção em dois compostos de milho (Zea mays L.). Piracicaba: USP/ESALQ, 1978. 71p. Dissertação (Mestrado).

CRUZ, C. D.; CARNEIRO, P.C.S. Modelos biométricos aplicados ao melhoramento genético. Viçosa: Editora UFV, 2003. $585 \mathrm{p}$.

EL-BAGOURY, O.H.; EL-SHOUNY, K.A.; AL-AHMAD, S.A.; IBRAHIM, K.I.M. Genetic parameters of some agronomic traits in yellow maize under two planting dates. Arab Universities Journal of Agricultural Sciences, v.13, p. 309-325, 2005.

FALCONER, D.S.; MACKAY, T.F.C. Introduction to quantitative genetics. 4 ed. Harlow: Pearson Education, 1996. $464 \mathrm{p}$.

FARIAS NETO, A.L.; MIRANDA FILHO, J.B. Genetic correlation between traits in the ESALQ-PB1 maize population divergently selected for tassel size and ear height. Scientia Agricola, v.58, p.119-123, 2001.

GARCIA, F.Q. Potencial do Composto Flintisa Anão de milho para melhoramento em condições de alta densidade populacional. Ilha Solteira: UNESP/FE, 2005. 84p. Dissertação (Mestrado).

GERALDI, I.O.; MIRANDA FILHO, J.B.; VENCOVSKY, R. Estimates of genetic parameters for tassel characters in maize (Zea mays L.) and breeding perspectives. Maydica, v.30, p.114,1985 .

HALlAUER, A.R.; MIRANDA FILHO, J.B. Quantitative genetics in maize breeding. 2 ed. Ames: Iowa State University Press, 1995. 468p

KASSOUF, A.L.; MIRANDA FILHO, J.B. Variabilidade genética e endogamia na população de milho ESALQ-PB1. In: CONGRESSO NACIONAL DE MILHO E SORGO, Maceió, 1984. Anais. Brasília: EMBRAPA-DDT, 1986. p.119-131.

KIESSELBACH, T.A. Corn investigations. Nebraska Agricultural Experiment Station Research Bulletin, v.20, p.5-151, 1922.

LIMA, M.; PATERNIANI, E. Estimativas de parâmetros genéticos e fenotípicos em progênies de meios irmãos de milho (Zea mays L.) ESALQ-VD2-MI-HSIII e suas implicações no melhoramento. Relatório Científico do Instituto de Genética. ESALQUSP, v.11, p.84-89, 1977.

LIMA, T.S.O. Avaliação das capacidades geral e específica de combinação e correlação entre caracteres em oito populações de milho (Zea mays L.). Viçosa: UFV, 1977. 71p. Dissertação (Mestrado) 
LORDELO, J.A.C. Parâmetros genéticos das populações de milho Piranão VD-2 e Piranão VF-1. Piracicaba: USP/ESALQ, 1982. 63p. Dissertação (Mestrado).

LYNCH, M.; WALSH, B. Genetics and analysis of quantitative traits. Sunderland: Sinauer, 1997. 980p.

MIRANDA FILHO, J.B. Breeding methodologies for tropical maize. In: BRANDOLINI, A.; SALAMINI, F. (Ed.) Breeding strategies for maize production improvement in the tropics. Rome: FAO, 1985. p.177-206.

MIRANDA FILHO, J.B. Cruzamentos dialélicos e síntese de compostos de milho (Zea mays L.) com ênfase na produtividade e no porte da planta. Piracicaba: USP/ESALQ, 1974. 116p. Tese (Doutorado)

MIRANDA FILHO, J.B. Exotic germplasms introduced in a Brazilian maize breeding program. Brazilian Journal of Genetics, v.15, p.631-642, 1992 .

MIRANDA FILHO, J.B.; GORGULHO, E.P. Yield potential and variability of two maize composites. Brazilian Journal of Maize and Sorghum, v.2, p.90-98, 2003.

MOCK, J.J.; PEARCE, R.B. An ideotype of maize. Euphytica, v.24, p.613-623, 1975.

PATERNIANI, E. Influence of tassel size on ear placement in maize (Zea mays L.). Maydica, v.26, p.85-91, 1981.

PATERNIANI, M.E.A.G.Z.; SAWAZAKI, E.; GALLO, P.B.; LUDERS, R.R.; SILVA, R.M. Estimates of genetic parameters in a maize composite and potential for recurrent selection. Crop Breeding and Applied Biotechnology, v.4, p.81-85, 2004.

RISSI, R. Estimação de parâmetros genéticos em duas subpopulações da variedade de milho (Zea mays L.) Piranão. Piracicaba: USP/ ESALQ, 1980. 87p. Dissertação (Mestrado).

SALAMI, A.E.; ADEGOKE, S.A.O.; ADEGBITE, O.A. Genetic variability among cultivars grown in Ekiti-State, Nigéria. Middle-East Journal of Scientific Research, v.2, p.9-13, 2007.

SAMPAIO, N.F. Propriedades genéticas e potencial para o melhoramento dos compostos de milho (Zea mays L.) ESALQPB4 e ESALQ-PB5. Piracicaba: USP/ESALQ, 1986. 105p. Dissertação (Mestrado).

SANTOS, M.X.; NASPOLINI FILHO, V. Estimativas de parâmetros genéticos em três ciclos de seleção entre e dentro de famílias de meios irmãos no milho (Zea mays L.) Dentado Composto Nordeste. Brazilian Journal of Genetics, v.9, p.307-319, 1986
SHULL, G.H. The composition of a field of maize. American Breeding Association Report, v.4, p.296-301, 1908.

SOARES FILHO, W.S. Características fenotípicas e genéticas das populações de milho (Zea mays L.) braquítico Piranão-VD2B e Piranão-VF1B. Piracicaba: USP/ESALQ, 1987. 185p. Tese (Doutorado).

SOUZA JR., C.L. Variabilidade genética em milho e relações com a seleção recorrente intra e interpopulacional. Piracicaba: USP/ ESALQ, 1983. 151p. Tese (Doutorado).

SOUZA JR., C.L.; GERALDI, I.O.; ZINSLY, J.R. Influence of tassel size on the expression of prolificacy in maize (Zea mays L.). Maydica, v.30, p.321-328, 1985.

VALOIS, A.C.C. Eficiência comparativa de quatro métodos de seleção em uma população melhorada de milho (Zea mays L.). Piracicaba: USP/ESALQ, 1982. 119p. Tese (Doutorado).

VENCOVSKY, R. Herança quantitativa. In: PATERNIANI, E.; VIEGAS, G.P. (Ed.) Melhoramento e produção do milho. Campinas: Fundação Cargill, 1987. cap.5, p.137-212.

VENCOVSKY, R.; BARRIGA, P. Genética biométrica no fitomelhoramento. Ribeirão Preto: Sociedade Brasileira de Genética, 1992. 496p.

VENCOVSKY, R.; MIRANDA FILHO, J.B.; SOUZA JR., C.L. Quantitative genetics and corn breeding in Brazil. In: WEIR, B.; EISEN, E.J.; GOODMAN, M.M.; NAMKOONG, N. (Ed.) Second International Conference on Quantitative Genetics. Proceedings. Sunderland: Sinauer, 1987. cap.42, p.465-477.

YAZDI-SAMADI, B.; ZALI, A.A.; TALEEI, A.; REZAIE, A.H.; REZAIE, A.M.; ZEINNALI, H. An estimate of some genetic parameters in corn (Zea mays L.) base on diallel crossing system. Iranian journal of Agricultural Sciences, v.35, p.337-345, 2004.

ZIVANOVIC, T.; SECANSKI, M.; TODOROVIC, G. Components of genetic variability and heritability of the number of rows per ear in silage maize. Biotechnology in Animal Husbandry, v. 21, p.109-121, 2005

Received September 09, 2006

Accepted October 01, 2007 